\title{
Socio-personal and Economic Analysis of Apiculture Enterprise in Hadauoti Region of Rajasthan
}

\author{
T.C. Verma, K.C. Meena, Subhash Aswal and D.K. Singh \\ Krishi Vigyan Kendra, Anta-Baran, Agriculture University, Kota, Rajasthan, India \\ *Corresponding author: vermactsmspp@gmail.com
}

\begin{abstract}
This study was undertaken with the objective to study the socio-personal profile of the successful beekeepers and the economic analysis of stationary and migratory apiculture in the Hadauti region of Rajasthan. The average size of migratory apiary units was found to be 192 hives and in case of stationary apiary units on an average there were 78 hives. The analysis of the socio-personal characteristics of the respondents revealed that the majority of the successful bee-keepers were in young age group, farming as major occupation along with bee keeping, high level of extension contact and maximum bee keepers were from other backward category background. The results depicted that the majority of bee keepers were from farming background and they took beekeeping as subsidairy occupation. However, unemployed youth were engaged with migratory apiculture and they adopt bee keeping as their main occupation. The five year average of honey production from migratory apiary units was $40.97 \mathrm{~kg} / \mathrm{hive}$, where as it was only $28.33 \mathrm{~kg} /$ hive for stationary apiary units. The cost-benefit of both migratory and stationary apiary units was found to be 2.61 and 4.00 in the year 2014-15 respectively. Overall, five year average, cost benefit ratio was workout 2.34 for stationary and 3.36 for migratory bee keeping entreprise during the year 2011-2015. It was evident from the results that the net return of bee keepers increased with the increase in the number of colonies.
\end{abstract}

Keywords: Apiculture, Economic analysis, Socio-personal profile, Cost benefit ratio

Beekeeping is becoming a very fascinating occupation day by day and the economic returns from this venture are quite high then the investment required. Apiculture does not bring any pressure on agriculture land and it produces honey, beeswax, pollen, propolis from the flowers which otherwise dry up in nature and go waste. Beekeeping is advocated to improve human welfare by alleviating poverty through increased household income, biodiversity conservation, food and nutritional security, raw material for industries and enhance environmental resilience (Ajao and Oladimeji 2013). Beekeeping plays a crucial role in the present context of commercialization of agriculture and liberalization of economy. It covers entire scope of honey bee resources, bee products, beekeeping practices, pollination services and their interface with business systems and environment integrity.
The profession of bee-keeping offers an immense potential for providing employment to rural masses in India where many crops, vegetables, evergreen trees, forests etc. provide required flora. The distinctive feature of beekeeping is the small capital investment required as compared to other industries. Furthermore, it does not need raw material in usual sense as nature provides the same in the form of nectar and pollen. It can be carried out by all age groups, i.e. by men, women, grownup children and even by physically handicapped and retired person (Monga and Manocha, 2011). It produces honey, beeswax, pollen, propolis from the flowers which can be sold out to earn income. If conditions are favourable, level of bee-keeping can be increased to semi-commercial or commercial level. 
$\mathrm{KVK}$, Anta is only one first line extension institute in the Baran District which established by the Indian Agricultural Research Council, New Delhi to promote farmers, women, and youth to adoption of latest agricultural technologies and establish their own enterprise related to agriculture \& allied sectors. The Kendra since its establishment has directed its efforts towards agricultural development in the district and bringing about entrepreneurship and skills among practitioners of agriculture and rural youth with a view to ensure livelihood security. The Krishi Vigyan Kendra, Anta -Baran are providing vocational trainings on beekeeping for generating employment among unemployed rural youth. However, for the effective popularization of apiculture in the farming communities, it was necessary to identify the socio-personal profile of successful beekeepers and the cost and return of bee-keeping to understand the profitability of the bee-keeping enterprise. This type of investigation was also important in context of policy making regarding bee-keeping. Therefore, the present study was undertaken with the objective to study the socio-personal profile of the successful bee-keepers and the economic analysis of apiculture enterprise in the Hadauti region of Rajasthan.

\section{MATERIALS AND METHODS}

Present investigation was conducted in Baran district of Hadauti region of Rajasthan. Krishi Vigyan Kendra, Anta-Baran was conducted a total 8 training programmes on bee-keeping during the years 2010-11 to 2015-16 and total 232 rural youth/farmers were trained. Out of these, 56 continuous adopters of bee-keeping were selected for the present study. They were grouped in to two categories i.e. Migratory units (38) and Stationary units (18). Farther, three sub-categories of these selected bee keepers were prepared on the basis of number of colonies i.e. small scale enterprise $<100$ hives), medium scale enterprise (between 100-200 hives) and large scale enterprise ( $>200$ hives). An interview schedule was developed to collect the data regarding socio-personal profile of the respondents and economic analysis of beekeeping enterprise. The data collected from the respondents were tabulated and analysed by using frequency and percentage. The cost and benefit sides were separately computed and the cost side divided the benefit side to compute the $\mathrm{BC}$ ratio. The cost items were grouped into two categories, i.e., (i) non-recurring costs and (ii) recurring costs. Total non-recurring cost includes cost on hives, bee hives, honey extractor, bee keeping kit and other miscellaneous items. The total recurring included, migration charges, labour cost, empty hive cost, other miscellaneous costs including depreciation as well as interest on non-recurring cost. The benefit cost ratio was computed by using the following formula:

$$
\text { B: } \mathrm{C} \text { ratio }=\frac{\text { Total returns }}{\text { Total recurring cost }}
$$

\section{RESULTS AND DISCUSSION}

Socio-personal profile of the beekeepers: The sociopersonal profile of the bee keepers with respect to age, level of education, occupation, caste, land holdings and extension contact is shown in Table 1. It was found that majority of stationary bee keepers were in young age group (55.56\%) followed by middle age group (44.44\%) and none stationary bee keepers were in old age group. In case of migratory bee keepers, the majority of respondents were also in young age group (73.68\%) followed by middle age group (23.68\%) and old age group (2.64\%) respectively. Overall, same trend was found that the majority of the successful bee-keepers were in young age group $(67.86 \%)$ and remainings were in the middle age $(30.36 \%)$ and old age group $(1.78 \%)$, respectively. This shows that bee-keeping enterprise can be successfully promoted in rural areas for creating self- employment among rural youth and also practising farmers. These results were in line with the findings of the Moniruzzaman and Rahman (2009).

The Maximum number ( $44.44 \%$ ) of the stationary beekeepers were having education up to metriculation $(10+2$ level), followed by middle level (33.34\%), graduation level (22.22\%) and none of the stationary bee keepers were post graduation level. In case of migratory bee keepers, the maximum number of respondents $(42.10 \%)$ were having education up to metriculation $(10+2$ level), followed by middle level $(34.22 \%)$, graduation level $(15.79 \%)$ and post graduation level $(7.89 \%)$, respectively. Overall, same trend was found that the maximum number of respondents $(42.86 \%)$ were having education up to metriculation $(10+2$ level), followed by middle 
Table 1: Socio-personnal charactristis of the bee keepar

\begin{tabular}{|c|c|c|c|c|c|c|c|}
\hline \multirow[t]{2}{*}{ Parameters } & \multirow[t]{2}{*}{ Category } & \multicolumn{2}{|c|}{ Stationary } & \multicolumn{2}{|c|}{ Migratory } & \multicolumn{2}{|c|}{ Total } \\
\hline & & No. & Percent & No. & Percent & No. & Percent \\
\hline \multirow[t]{4}{*}{ Age } & Young age (18-35 year) & 10 & 55.56 & 28 & 73.68 & 38 & 67.86 \\
\hline & Middle age (36-49 year) & 08 & 44.44 & 09 & 23.68 & 17 & 30.36 \\
\hline & Old age (50 year and above) & 00 & 00.00 & 01 & 02.64 & 01 & 1.78 \\
\hline & Total & 18 & 100 & 38 & 100 & 56 & 100 \\
\hline \multirow[t]{5}{*}{ Level of Education } & Upto Middle & 06 & 33.34 & 13 & 34.22 & 19 & 33.93 \\
\hline & Matriculation $(10+2)$ & 08 & 44.44 & 16 & 42.10 & 24 & 42.86 \\
\hline & Graduation & 04 & 22.22 & 06 & 15.79 & 10 & 17.85 \\
\hline & Post Graduation & 00 & 00.00 & 03 & 07.89 & 03 & 5.36 \\
\hline & Total & 18 & 100 & 38 & 100 & 56 & 100 \\
\hline \multirow[t]{4}{*}{ Occupational } & Farming+ Beekeeping & 16 & 88.89 & 23 & 60.53 & 39 & 69.65 \\
\hline & Farming + Business + Beekeeping & 02 & 11.11 & 02 & 05.26 & 04 & 7.14 \\
\hline & Only Beekeeping & 00 & 00.00 & 13 & 34.21 & 13 & 23.21 \\
\hline & Total & 18 & 100 & 38 & 100 & 56 & 100 \\
\hline \multirow[t]{5}{*}{ Caste } & Schedualed Caste & 04 & 22.22 & 03 & 07.89 & 07 & 12.50 \\
\hline & Schedualed Tribe & 03 & 16.67 & 12 & 31.58 & 15 & 26.78 \\
\hline & Other backword Class & 08 & 44.44 & 16 & 42.10 & 23 & 41.07 \\
\hline & Genral Caste & 03 & 16.67 & 07 & 18.43 & 11 & 19.65 \\
\hline & Total & 18 & 100 & 38 & 100 & 56 & 100 \\
\hline \multirow[t]{5}{*}{ Land holding } & Marginal (<1.0 ha) & 04 & 22.22 & 03 & 07.89 & 07 & 12.50 \\
\hline & Small (1.0-2.0 ha) & 07 & 38.89 & 20 & 52.63 & 27 & 48.21 \\
\hline & Medium (2.0-10 ha) & 06 & 33.33 & 07 & 18.43 & 13 & 23.21 \\
\hline & Large (>10 ha) & 01 & 05.56 & 08 & 21.05 & 09 & 16.08 \\
\hline & Total & 18 & 100 & 38 & 100 & 56 & 100 \\
\hline \multirow[t]{4}{*}{ Extension contact } & Low & 04 & 22.22 & 02 & 5.26 & 06 & 10.72 \\
\hline & Moderate & 12 & 66.67 & 05 & 13.16 & 17 & 30.35 \\
\hline & High & 02 & 11.11 & 31 & 81.58 & 33 & 58.93 \\
\hline & Total & 18 & 100 & 38 & 100 & 56 & 100 \\
\hline
\end{tabular}

level $(33.93 \%)$, graduation level $(17.85 \%)$ and post graduation level (5.36\%), respectively. These results were in accordance with the study conducted by Lal et al. (2012) and Mujuni et al. (2012). This is supports the idea that in rural areas where youth does not have requisite education for gaining employment can be engaged in the bee-keeping enterprise.

Further, the Table 1 showed that the majority of the stationary beekeepers $(88.89 \%)$ were having farming as major occupation along with bee keeping. Only, few $(11.11 \%)$ stationary bee keeper were from farming+ buisness cadre and none of the stationary beekeepers were without farming or buisness cadre. In case of migratory units, the majority (60.53\%) was also having farming as major occupation along with bee keeping followed by only bee keeping (34.21\%) and farming+ buisness+beekeeping (5.26\%) respectively. It might be due to unempoloyed youth were engaged with migratory units and they had adopted bee keeping as their main occupation. Overall, it was found that the majority of the beekeepers (69.65\%) were having farming as major occupation along with bee keeping and about 23.21 per cent had adopted bee keeping as main occupation. Only 7.14 per cent of the bee-keepers were from the business cadre. The results depicted that majority of the bee-keepers had farming background and they took the bee-keeping as subsidiary occupation due to availability of bee flora around their locality and positive outcome of beekeeping on crop yields. Data (Table 1) revealed that maximum of the bee keepers $(41.07 \%)$ were from other backward category background followed by scheduled tribe $(26.78 \%)$, general category $(19.65 \%)$ 
and scheduled caste $(12.50 \%)$, respectively. This might be due to the fact that interested candidates were selected in the training programmes on beekeeping by KVK, Baran. Qaiser et al. (2013); Sharma and Dhaliwal, (2014) and Gurdeep et al. (2016) has reported the same results.

The Table 1 also depicted that about half (48.21\%) of bee-keepers were having small size of land holding (1.0-2.0 ha), followed by medium size $(23.21 \%)$ of land holding (2.0-10.0 ha), large size $(16.08 \%)$ of land holding (>10 ha) and marginal size (12.50\%) of land holding (less than 1.0 ha), respectively. It was observed that the majority of the stationary bee-keepers $(66.67 \%)$ were having moderate level of extension contact followed by high level of extension contact $(22.22 \%)$ and low level of extension contact $(11.11 \%)$ respectively. In case of migratory, the majority of the bee-keepers $(81.58 \%)$ were having high level of extension contact followed by moderate level of extension contact $(13.16 \%)$ and low level of extension contact $(5.26 \%)$ respectively. The overall, majority of the bee-keepers (58.93\%) were having high level of extension contact followed by moderate level of extension contact $(30.35 \%)$ and low level of extension contact $(10.72 \%)$ with the experts and line departments, respectively. This might be due to the fact that the beekeepers were continue contact with KVK scientists, Department of Horticulture officials and other stakeholders for gaining recent knowledge and other requirements regarding enhancing the profitability in beekeeping. This indicates that the economic status of the farmers can be improved by motivating them to adopt bee-keeping enterprise.

\section{Economic analysis of bee-keeping enterprise}

Bee-keepers got income from sale of honey, wax and pollen. Major expenditure was initial cost on the purchase of bee boxes, colonies, honey extracting machine, gloves, veil and other tools. While calculating cost, all fixed and variable costs were included in the study. The details of the total cost and gross returns of different bee-keepers based on the information collected from individual bee-keepers have been calculated. The net returns were calculated by subtracting total cost from gross returns. The economics of individual beekeeper was calculated based on the information provided by bee-keepers.

Economic analysis of stationary apiary units: The five year average cost and return was showns in Table 2 depicts that total nine stationary bee-keepers were practising bee-keeping on small scale followed by medium scale (06) and large scale (03) bee keeping entreprise, respectively. The average honey production was work out $28.33 \mathrm{~kg} /$ colony and sale rate was $₹ 127.17 / \mathrm{kg}$ during the year 2011-2015. The average net returns were around 0.83 lacs for small scale, 2.70 lacs for medium scale and 5.19 lacs for the large scale stationory bee keeping entreprise, respectively. The cost benefit ratio was 2.54 for large scale followed by 2.16 for medium scale and 2.08 of small scale, respectively. Overall average, cost benefit ratio was workout 2.34 for stationary bee keeping entreprise during the year 2011-2015. It was found that the net retrun of bee keepers increased with the increase in the number of hives.

The economic analysis of 18 selected stationary apiary units during the year 2014-15 was presented in Table 3. The data revealed that on an average there were 78 bee-keeping colonies per bee keeper for which total average non-recurring cost was found to be ₹ $2,82,030$. The average total recurring cost which includes cost for interest on nonrecurring cost, depreciation, annual labour charges and other miscellaneous charges was found to be $₹ 88,218$. The findings further show that on an average $28 \mathrm{~kg}$ of honey was produced from a single

Table 2: Five year average cost and net returns for stationary apiary units during 2011-2015

\begin{tabular}{cccccccc}
\hline Sub-categoeries & $\begin{array}{c}\text { No.of } \\
\text { beekeeper }\end{array}$ & $\begin{array}{c}\text { Average honey } \\
\text { produce (kg/ } \\
\text { colony) }\end{array}$ & $\begin{array}{c}\text { Average } \\
\text { sale/kg }\end{array}$ & $\begin{array}{c}\text { Gross returns } \\
\text { (₹) }\end{array}$ & Cost (₹) & Net returns & B C ratio \\
\hline Small scale & 9 & 28.56 & 126.67 & 160653 & 77418 & 83235 & 2.08 \\
Medium scale & 6 & 28.33 & 128.33 & 539940 & 249658 & 270282 & 2.16 \\
Large scale & 3 & 27.67 & 126.33 & 856160 & 336667 & 519493 & 2.54 \\
Total & 18 & 28.33 & 127.17 & 416333 & 178039 & 218294 & 2.34 \\
\hline
\end{tabular}


Table 3: Economic analysis of stationary apiary units (78 hives) during Year 2014-2015 ( $\mathrm{n}=18$ )

\begin{tabular}{|c|c|c|c|}
\hline Sl. No. & Items & No. Items & Cost (₹) \\
\hline A & Non-recurring costs & & \\
\hline 1 & Bee Boxes (hives @ ₹ 850 hives $^{-1}$ & 78 & 66300 \\
\hline 2 & Bee colonies @ 10 frame @ ₹ 250 hive $^{-1}$ & 78 & 195000 \\
\hline 3 & Honey Extractor & 1 & 4500 \\
\hline 4 & Iron stand & 78 & 4680 \\
\hline 5 & Bee veil & 5 pairs & 350 \\
\hline 6 & Tool Kit & 1 & 500 \\
\hline 7 & Brush & 2 & 100 \\
\hline 8 & Hand gloves & 5 pairs & 400 \\
\hline 9 & Nylon net & 1 & 1200 \\
\hline 10 & Tent, Utensils etc. & - & 5000 \\
\hline \multirow[t]{2}{*}{11} & Other miscellaneous items & - & 4000 \\
\hline & Total Non-recurring cost & & 282030 \\
\hline B & Recurring Cost & & \\
\hline 1 & Empty Boxes (25\%) & 20 & 17000 \\
\hline 2 & Iron stand & 20 & 1200 \\
\hline 3 & Wax sheets (₹ 25 sheet $\left.^{-1}\right)$ & 156 & 3900 \\
\hline 4 & Sulphur dust (10gm/box) & $2 \mathrm{~kg}$ & 500 \\
\hline 5 & Sugar $(3 \mathrm{~kg} / \mathrm{box})$ & $234 \mathrm{~kg}$ & 6552 \\
\hline 6 & Migration Charges/year & 00 & 00 \\
\hline 7 & Labour charges & 00 & 00 \\
\hline \multirow[t]{2}{*}{8} & Other miscellaneous items, formic acid etc. & - & 10000 \\
\hline & Interest and Depreciation & & \\
\hline 9 & Interest on Non-recurring cost@ $14 \%$ & & 37846 \\
\hline 10 & Interest on recurring cost@ $14 \%$ of 6 months & & 2517 \\
\hline \multirow[t]{2}{*}{11} & Depreciation cost @ 10\% (excluding Bee colonies) & & 8703 \\
\hline & Total Recurring cost & & 88218 \\
\hline $\mathrm{C}$ & Economic returns & & \\
\hline 1 & Production of honey (@ $28 \mathrm{~kg} \mathrm{hive}^{-1}$ ) sold at ₹ $132 \mathrm{~kg}^{-1}$ ) & $2184 \mathrm{~kg}$ & 292656 \\
\hline 2 & Sale of bee wax (@ $0.8 \mathrm{~kg} \mathrm{hive}^{-1}$ ) 38.4 sold at ₹ $175 \mathrm{~kg}^{-1}$ & 62.4 & 10920 \\
\hline \multirow[t]{4}{*}{3} & Sale of 60 honey bee frames @ 230 frame $^{-1}$ & 60 & 15000 \\
\hline & Total Returns & & 318576 \\
\hline & Net Return (C-B) & & 230358 \\
\hline & BC Ratio (C/B) & & 3.61 \\
\hline
\end{tabular}

hive and total average honey production from single stationary unit was found to be $2,184 \mathrm{~kg}$. From the sale of this honey @ ₹ 132/kg the single respondent has earned average ₹ 2, 92,656. In addition to honey there was average ten per cent increase in honey bees population (60 hives) worth ₹ 15000 and an on an average 0.8 per cent increase in wax production $(175 \mathrm{~kg})$ from which additional income from sale of wax i.e. ₹ 10920. A net average return from a stationary apiary unit was found to be ₹ 2, 30,358 and the benefit cost analysis of stationary units was found to be 3.61. These findings were supported with the results of Qaiser et al. (2013) and Gurdeep et al. (2016).

Economic analysis of migratory apiary units: The Table 3 depicts that the five year average cost and return of migratory apiray. It was found that total 16 bee-keepers were practising bee-keeping on medium scale and the equal number of migratory beekeepers was practising small scale (11) and large scale (11). The average honey production was work out 40.97 $\mathrm{kg} /$ colony and average sale rate was $₹ 130.82$ per 
Table 4: Five year average cost and net returns for migratory apiary units during 2011-2015

\begin{tabular}{cccccccc}
\hline Sub-categoeries & $\begin{array}{c}\text { No. of } \\
\text { beekeeper }\end{array}$ & $\begin{array}{c}\text { Average honey } \\
\text { produce (kg/ } \\
\text { colony) }\end{array}$ & $\begin{array}{c}\text { Average sale/ } \\
\text { kg }\end{array}$ & $\begin{array}{c}\text { Gross returns } \\
\text { (₹) }\end{array}$ & $\begin{array}{c}\text { Cost } \\
\text { (₹) }\end{array}$ & Net returns & $\begin{array}{c}\text { B C } \\
\text { ratio }\end{array}$ \\
\hline Small scale & 11 & 39.82 & 131.91 & 370490 & 120260 & 250230 & 3.08 \\
Medium scale & 16 & 42.19 & 129.50 & 885150 & 263130 & 623535 & 3.36 \\
Large scale & 11 & 40.36 & 131.64 & 1609538 & 468360 & 1145782 & 3.44 \\
Total & 38 & 40.97 & 130.82 & 945861 & 281182 & 666650 & 3.36 \\
\hline
\end{tabular}

Table 5: Economic analysis of migratory apiary units (192 hives) during Year 2014-2015 (n=38)

\begin{tabular}{|c|c|c|c|}
\hline S1. No. & Items & No. Items & Cost (₹) \\
\hline A & Non-recurring costs & & \\
\hline 1 & Bee Boxes (hives @ ₹ 850 hives $^{-1}$ & 192 & 163200 \\
\hline 2 & Bee colonies@ 10 frame @ ₹ 250 hive $^{-1}$ & 192 & 480000 \\
\hline 3 & Honey Extractor & 1 & 6000 \\
\hline 4 & Iron stand & 192 & 11520 \\
\hline 5 & Bee veil & 5 pairs & 350 \\
\hline 6 & Tool Kit & 1 & 500 \\
\hline 7 & Brush & 2 & 100 \\
\hline 8 & Hand gloves & 5 pairs & 400 \\
\hline 9 & Nylon net & 1 & 1200 \\
\hline 10 & Tent, Utensils etc. & - & 10000 \\
\hline \multirow[t]{2}{*}{11} & Other miscellaneous items & - & 10000 \\
\hline & Total Non-recurring cost & & 683270 \\
\hline B & Recurring Cost & & \\
\hline 1 & Empty Boxes (25\%) & 38 & 32300 \\
\hline 2 & Iron stand & 38 & 2280 \\
\hline 3 & Wax sheets (₹ 25 sheet $\left.^{-1}\right)$ & 380 & 9500 \\
\hline 4 & Sulphur dust (10gm/box) & $4.5 \mathrm{~kg}$ & 1150 \\
\hline 5 & Sugar $(3 \mathrm{~kg} / \mathrm{box})$ & $800 \mathrm{~kg}$ & 22400 \\
\hline 6 & Migration Charges/year & 2 & 144000 \\
\hline 7 & Labour charges & 48 & 40800 \\
\hline \multirow[t]{2}{*}{8} & Other miscellaneous items, formic acid etc. & - & 10000 \\
\hline & Interest and Depreciation & & \\
\hline 9 & Interest on Non-recurring cost@ 14\% & & 35178 \\
\hline 10 & Interest on recurring cost@ 14\% of 6 months & & 17931 \\
\hline \multirow[t]{2}{*}{11} & Depreciation cost @ 10 \% (excluding Bee colonies) & & 20327 \\
\hline & Total Recurring cost & & 335866 \\
\hline $\mathrm{C}$ & Economic returns & & \\
\hline 1 & Production of honey (@ $48 \mathrm{~kg} \mathrm{hive}^{-1}$ ) sold at ₹ $136 \mathrm{~kg}^{-1}$ ) & $9216 \mathrm{~kg}$ & 1253376 \\
\hline 2 & Sale of bee wax (@ $0.8 \mathrm{~kg}$ hive ${ }^{-1}$ ) 38.4 sold at ₹ $175 \mathrm{~kg}^{-1}$ & 249.6 & 43680 \\
\hline \multirow[t]{4}{*}{3} & Sale of 60 honey bee frames @ 230 frame $^{-1}$ & 190 & 46550 \\
\hline & Total Returns & & 1343606 \\
\hline & Net Return (C-B) & & 1007740 \\
\hline & BC Ratio (C/B & & 4.00 \\
\hline
\end{tabular}


kilogram of honey during the year 2011-2015. The average net returns were around 2.50 lacs for small scale, 6.23 lacs for medium scale and 11.45 lacs for the large scale migratory bee keeping entreprise, respectively. The cost benefit ratio was 3.44 for large scale followed by 3.36 for medium scale and 3.08 of small scale, respectively. Overall average, cost benefit ratio was workout 3.36 for migratory bee keeping entreprise during the year 2011-15. This might be due to the fact that the year round honey productuion and fatching good market price from migratory units as compaired to stationary units. It was also evident from the results that the net return of bee keepers increased with the increase in the number of colonies. Kumar (2012) also observed that returns from bee-keeping increases with increase in number of colonies.

The economic analysis of 38 selected migratory bee keeping units was presented in Table 5. The data revealed that on an average there were 192 beekeeping colonies per respondent for which total average non recurring cost was found to be Rs. 6, 83,270 . Total average recurring cost which includes cost for interest on non-recurring cost, depreciation, annual migration charges, annual labour charges and other miscellaneous charges was found to be 3, 35,866 . The findings further show that on an average $48 \mathrm{~kg}$ of honey was produced from a single hive and total average honey production from migratory apiary unit (192 hives) was found to be 9,216 kg. From the sale of this honey @ ₹ 136/kg the single respondent has earned average $₹ 12$, 53,376. In addition to honey there was average ten per cent increase in honey bees population (60 hives) worth $₹ 46,550$ and an on an average 0.8 per cent increase in wax production $(175 \mathrm{~kg})$ from which additional income from sale of wax i.e. ₹ 43,680. A net average return from a migratory apiary unit was found to be $₹ 10,07,740$. The benefit cost analysis of migratory units was found to be 4.00. Qaiser et al. (2013) and Gurdeep et al. (2016) has reported cost benefit ratio of 1.44 in with 170 colonies in Pakistan and 2.77 in with 65 colonies in Panjab (India).

\section{CONCLUSION}

It may be concluded that bee keeping can be successfully promoted in rural area for creating self-employment among rural youth and practising farmers. Krishi Vigyan Kendras are playing a pivotal role in providing vocational trainings for generating employment to the rural youth. The majority of bee keepers were in young age group, it is a good sign for generating self employment for rural youth. The benefit-cost analysis of beekeeping was done to establish the returns from this enterprise. This indicated that beekeepers were substantial returns, which was a good source of income especially for the rural people. Migratory units had edge over stationary units as far economics is concerned. The efforts should be made to promote apiary on large scale in India by KVKs, State Deptt. of Hort \& other agencies involved in honey bee rearing jointly. Creating awareness regarding apiary, developing marketing facilities, trainings, making arrangement for availability of flora by road side plantation and easy credit facilities for rural people can have a positive impact on income enhancement and employment generation in rural areas. The study also concluded that the net return increases as number of colonies increases. Further, the profits can be enhanced further by involving the beekeepers in processing and self direct marketing to consumer.

\section{REFERENCES}

Ajao, A.M and Oladimeji, Y.U 2013. Assessment of contribution of Apicultural practices to Household income and poverty alleviation in Kwara State, Nigeria; International Journal of Science and Nature, 4(4): 687-698.

Ali, Syed and Jabeen, Urooj Afshan 2015. An assessment of contribution of beekeeping activities to household food scurity. International Journal of Research in Economics and Social Sciences, 5(5): 17-26.

Kumar, S. 2012. Bee-keeping-An ideal option for prosperity, Indian Farming, 62(3): 29-33.

Kumari, Anuradha Ranjan, Singh, Alka Singh, Neeraj and Singh, Meera. 2015. Assessing the effectiveness of apiculture training programme on rural women. Indian Res. J. Ext. Edu. (Special Issue), 15(4): 56-59.

Moniruzzaman, M. and Rahman, M.S. 2009. Prospects of beekeeping in Bangladesh, J. Bangladesh Agril. Univ., 7(1): 109-116.

Monga, K. and Manocha, A. 2011. Adoption and constraints of beekeeping in district Panchkula (Haryana). Livestock Research For Rural Development. Volume 23 (5), Article \#103. Retrieved August 22, 2016, from http://www.lrrd.org/lrrd23/5/ mong23103.htm

Majuni, A., Natukunda, K. and Kugonga, D.R. 2012. Factor affecting the adoption of beekeeping and associated technology in Busheny district, Western Uganda. Live Stock Research for Rural Development, 24(8). 
Quiser, T., Ali, M., Taj, S. and Akmal, N. 2013. Impact assessment of beekeeping in sustainable rural livelihood, COES and RJ- Journal of Social Science, 2(2): 82-90.

Ramesh Lal, Sharma, S.D., Sharma, J.K., Sharma, V. and Singh, D. 2012. Impact of bee-keeping training on socio-economic status of farmers and rural youths in Kullu and Mandi districts of Himachal Pradesh, J. Hum. Ecol., 39(3): 205-08.

Sharam, Karamjit and Dhaliwal, N.S. 2014. Socio-economic profile of successful beekeepers and profitability of bee keeping in muktsar district of Punjab. J. Krishi Vigyan, 2(2): 69-73.
Singh, K., Peshin, R. and Saini, S.K. 2010. Evaluation of agricultural vocational training programmes conducted by Krishi Vigyan Kendras in Indian Punjab. J. Agri. and Rural Dev. in Tropics and Subtropics, 111: 65-77.

Singh, Gurdeep Tiwari, Devinder and Yadav, S.P. 2016. Income enhancement and employment generation through apiculture enterprise for rural youth in Punjab. Indian Res. J. Ext. Edu. 16(1): 112-115.

Yirga, G. and Ftwi, K. 2010. Beekeeping for rural development its potentiality and constraints in eastern tigray, Northern Ethiopia, agricultural journal, 5(3): 201-204. 